\title{
NACHT, LRR and PYD Domains-Containing Protein 6
}

National Cancer Institute

\section{Source}

National Cancer Institute. NACHT, LRR and PYD Domains-Containing Protein 6. NCI

Thesaurus. Code C101308.

NACHT, LRR and PYD domains-containing protein 6 (892 aa, $99 \mathrm{kDa}$ ) is encoded by the human NLRP6 gene. This protein may be involved in the activation of the inflammatory response. 